\title{
CONTENT-BASED IMAGE RETRIEVAL USING EXPRESSION SENSITIVITY BY FUZZY INFERENCE SYSTEM
}

\author{
${ }^{a}$ Sukmawati Nur Endah, ${ }^{\text {bPriyo Sidik Sasongko, }{ }^{c} H e l m i e ~ A r i f ~ W i b a w a ~}$ \\ ${ }^{a, b, c}$ The Informatics Departement, Faculty of Mathemathics and Sciences, \\ Diponegoro University \\ E-Mail: sukmawati020578@gmail.com
}

\begin{abstract}
Abstrak
Sistem temu kembali citra dapat dibagi menjadi dua jenis yaitu berbasis konteks dan berbasis isi. Sistem temu kembali citra berbasis isi merujuk pada fitur citra seperti warna, tekstur, bentuk, semantika atau sensasi yang ditimbulkannya. Penelitian ini mengusulkan sebuah sistem temu kembali citra multi kueri berbasis sensasi dengan menggunakan sistem inferensi fuzzy. Multi kueri yang dimaksud adalah kueri sebagai masukannya dapat berupa citra ataupun teks. Penggolongan sensasi citra mengacu pada teori Itten yang terdiri dari sensasi hangat, sejuk, dingin, gundah dan hidup. Pembuatan sistem ini menggunakan dua sistem inferensi fuzzy. Sistem inferensi fuzzy yang pertama digunakan untuk menentukan warna keempat region yang dibagi sama rata dari suatu citra berukuran 256 x 256 . Hasil keluaran dari sistem inferensi fuzzy yang pertama merupakan masukan bagi sistem inferensi fuzzy yang kedua. Sistem inferensi fuzzy yang kedua digunakan untuk menentukan jenis sensasi dari citra tersebut. Dari 50 citra dan 20 responden tingkat keakuratan berdasarkan pengamatan responden untuk kueri teks sebesar $42 \%$, sedangkan untuk kueri citra sebesar 55\%. Penelitian ini dapat dikembangkan lebih lanjut untuk citra-citra yang lain seperti citra medis dengan kriteria-kriteria tertentu.
\end{abstract}

Kata kunci : sistem temu kembali citra, sensasi citra

\begin{abstract}
Image retrieval can be divided into two types context-based and the content-based. Image retrieval based on the content refers to the image features such as color, texture, shape, semantics or sensations. This paper addresses the content-base image retrieval system based on expression sensitivity. It can be image or text query for input the system. Based on Itten theory, expression sensitivity consist of warm, cold, relax, anxious, and life. The research system uses two fuzzy inference system. Firstly, fuzzy inference system is used to decide image region of color. The image size is $256 \times 256$ pixel. Output the first fuzzy inference system is input for the second fuzzy inference system. The second fuzzy inference system is used to determined expression sensitivity of image. Degree of accuracy based on respondent from 50 images and 20 respondents is $42 \%$ for text query and $55 \%$ for image query. The further research, it can be used for other image such as medical image with certain criteria.
\end{abstract}

Keywords: content-base image retrieval, expression sensitivity of image. 


\section{INTRODUCTION}

With the rapid technological developments, the amount of digital image data generated by the application of education, health, industry and science, including the arts increased sharply. For that we need a system that is able to help the user find the desired digital image. Image retrieval system is divided into two types, namely context-based (context) and content-based (content).

Image retrieval system based on the description of the context usually refers to images such as keywords of the image, while referring to the content-based image features such as color, texture, shape or combination of the features. System of content-based image retrieval is often referred to as content-base image retrieval (CBIR) [1].

In general, the attributes attribute of the image divided into a low level (low level) and attribute a high level (high level). Attribute is the low level visual attributes such as color, shape, texture and layout of the relationship. Attribute a high level is divided into two (2), namely a primitive semantic and the resulting sensation. Primitive semantics is an abstraction of the visual signs such as objects, roles and situations. The sensation is caused, among other impressions, emotions and meanings generated by the image on the observer. High level attributes obtained through a complex inference procedures on low-level attributes of the image [2] [3].

CBIR systems are made in general not represent the attributes of a high level [4] [5] [6] [7]. Zoran [3] and Alfina [2] have developed a retrieval system image to represent the image by using the theory of Itten [8] who formulated the relationship between the color compositions with the sensations of the observer. The results Alfina [2] based on fuzzy proven better than Zoran research [3] that without using a fuzzy approach. However, the results for some of the sensation is still relatively low and their query based solely on the text. Hence, in this study will be proposed a multi-image retrieval system using query-based sensation fuzzy inference system. Multi query in question is a query based on the example image (query by example) either from the template image (template image) and image files (image files) and a query based on the text. While the fuzzy inference system is used there are two types of fuzzy inference system to determine what kind of colors based on itten Runge sphere and fuzzy inference system to determine the type of sensation.

\section{ITTEN THEORY}

Itten theory formulates the relationship between the composition of colors in the painting and the sensations of the man who saw the painting [8]. Itten theory was formulated based on color classification by modeling called the Itten-Runge sphere. IttenRunge sphere-shaped spherical coordinate system in space. Itten-Runge sphere consists of 12 hue, each of which has five levels of brightness and three levels of saturation, so that amounted to 180 colors. Twelfth hue is present in all meridians of the Itten-Runge sphere, while the saturation increases with radius. Itten name the hue-hue is red, redorange, orange, orange-yellow, yellow, yellow-green, green, blue-green, blue, bluepurple, purple and purple-red. By using the Itten-Runge sphere, the relationship between the compositions of colors in the image with the resulting sensation can be described easily. Based on the color position on Itten-Runge sphere, Itten color combinations grouped into two types, namely a combination of contrasting colors and harmonious color combinations. Contrasting properties determine the degree of difference between one subject with the surrounding area. One example is the contrasting color composition complemented color pairs. According to Itten's theory, the colors are complementary color pairs whose position on the Itten-Runge sphere located opposite each other. While the color combination is harmonious color combinations that cause effects to the stability of the human eye. The combination of colors is obtained by connecting the colors of the Itten-Runge sphere so as to form regular shaped polygons such as equilateral triangles or squares.

Based on the Itten Theory, different color combinations create different sensations. For example adjacent complementary colors create a soothing or relaxing sensation of the observer. Table 1 displays the combinations of colors and sensations that are formulated by Itten [8]. 
Table 1. Itten Theory Of Sensation

\begin{tabular}{cl}
\hline Sensation & \multicolumn{1}{c}{ Color Combinations } \\
\hline Warm & $\begin{array}{l}\text { colors of yellow to purple-red in the } \\
\text { Itten-Runge sphere }\end{array}$ \\
Cold & $\begin{array}{l}\text { From purple to green-yellow on the } \\
\text { Itten-Runge sphere }\end{array}$ \\
relaxing & $\begin{array}{l}\text { Couple complementary colors are } \\
\text { located close together }\end{array}$ \\
anxious & $\begin{array}{l}\text { No upset there is a contrasting color } \\
\text { pairs (reinforced by the color yellow } \\
\text { and purple) } \\
\text { There is harmonious color } \\
\text { combinations }\end{array}$ \\
\hline
\end{tabular}

\section{SYSTEM OVERVIEW}

The main function of content-based image retrieval system can be found an image in groups of images with a certain sensation. The key used to find the image is input in the form of a query. In this developed system, a query input can be text or image queries. As for the output are images that have a sensation according to the query entered. System workflow is described in Figure 1.

The input query in this system has two types, the text query and image query. The handling of two types of queries is different. For the text query, because in this query can be known types of sensation, then no need to undergo further processing and will be processed by a search of sensation module. As for the query in the form of images, before being processed in a search in the search module sensation, going through the stages of the process as follows: size normalization into $256 \times 256$ pixels, the division into four regions, the determination of the color of each region, resulting in a kind of sensation and the value of the sensation.

Based on the theory of Itten, colors that determine the type of sensation is as follows.

1. Warm

The image is dominated by the color red purple, red, red orange, orange, yellow orange or yellow.

2. Relaxed

Following colors in each region is located adjacent to each other, the colors yellow and purple, orange yellow and blue, purple, blue and orange, green, blue and red orange, green and red and green yellow and red purple.

3. Depressed

In each region no contrasting pairs so that the image colors are not much different, such as red and red purple, red and red orange, orange-red and orange, orange and orange yellow, yellow orange and yellow, yellow and yellow green, green and yellow green, green and blue green, blue green and blue, blue and blue-violet, blue violet and purple and purple and red purple.

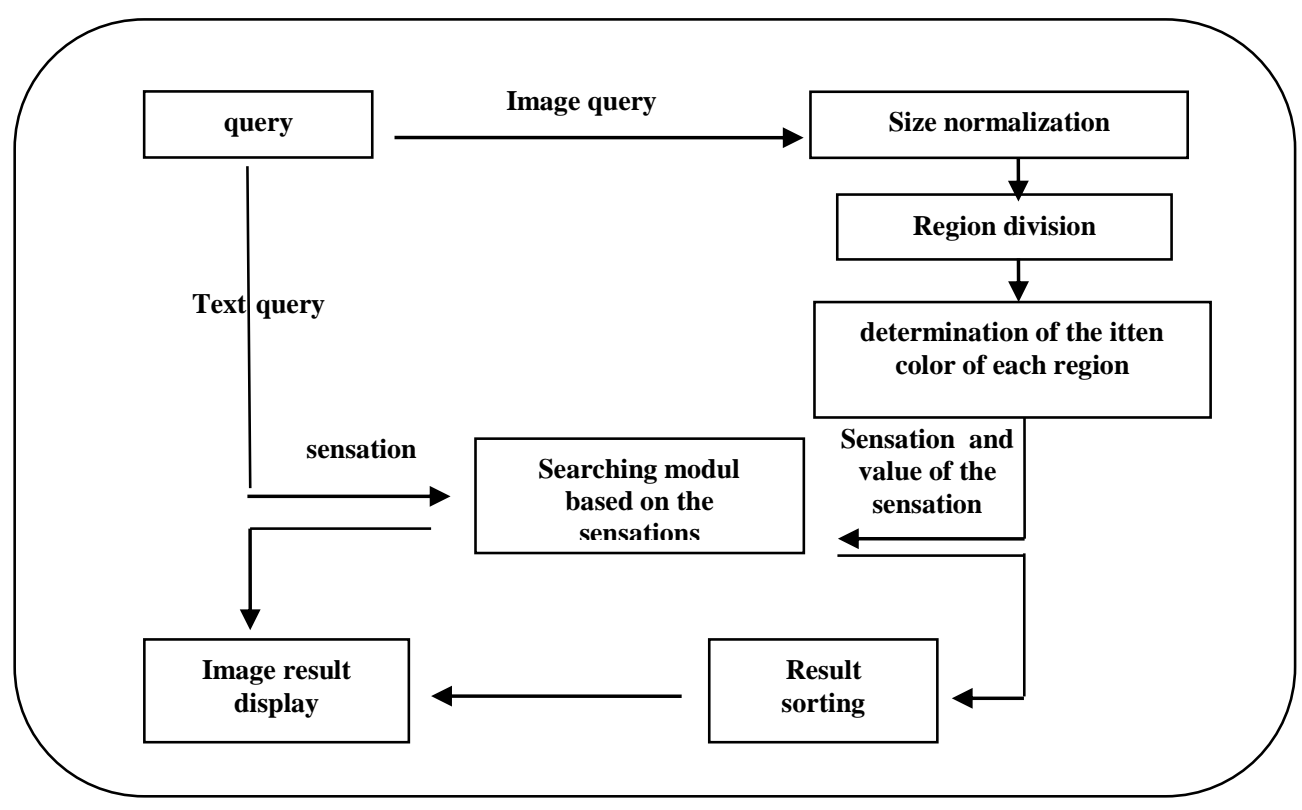

Figure 1. System workflow 
4. Life

Colors in this sensation is a harmonious combination of colors, namely yellow, red, blue, red orange, yellow, green, blue purple orange, green, purple orange yellow, green, blue, purple red: red, orange yellow, green, blue purple red orange, yellow, green, blue, purple and orange color combination, green yellow, blue and red purple.

5. Cold

These sensations in his region are dominated by purple, blue, purple, blue, green, blue, green or yellow green.

Then, as the acquired type of sensation to search, the system will perform a search in the database image. Search is done by calculating the value and type of sensation of any image data that is in the database with fuzzy inference engine sensation. To input a Image query, in addition to known types of desires sensation, also known value of the sensation, to calculate the difference in value from the image query sensation with the sensation of each image from the database so that the results of a search using a image query can be ordered by the sensation is most closely based on the value of this difference. As for the text query, all images had the sensation according to the query are displayed without sorting

\section{SYSTEM DESIGN}

The system is divided into several modules/functions, including: queries importing module, image processing module, fuzzy inference engine module, search module based on the query, and image data management module.

\section{Queries Importing Module}

The system can accept input of two types of queries, so in design of, intake module queries designed to receive input two queries, i.e. queries of the form of text and image queries. This module interacts directly with the users of the system.

Here is an explanation for the module with the text query and image queries

1. Text query. To input a text query, because the sensation of the image is limited to five pieces of sensation: a warm, relaxed, anxious, life, and cold, then to text query within its design is only given a limited choice in the fifth choice of the sensation.

2. Image query. A Image query, can receive image files from outside the system. Image file format is the standard format for image files includes jpg, jpeg, bmp, gif and png, and the file size and image size that is free because the inserted image will be normalized in the image processing module.

\section{Image Processing Module}

Processing module serves to cultivate the image of the query entered in the form of images. In the image processing module, the image coming from the insert query, would be normalized size to $256 \times 256 \mathrm{px}$. Then, if the image size is not proportionate it will be cropped (cut) with the benchmark is the top left so the size of a normal $256 \times 256$ px with a fixed proportion.

Once the images are normalized in this module image will be formed in four regions R1, R2, R3 and R4 as in Figure 2, which have a size of $128 \times 128$ pixels. Each region will contain the value of RGB (Red, Green, Blue) in which the average value for each color channel will be calculated. Then the average value of RGB become inputs in the fuzzy inference system, which will generate the kind of itten color of each region. Itten color and type as input in a fuzzy inference system module sensation for sensation is determined from the image inserted.

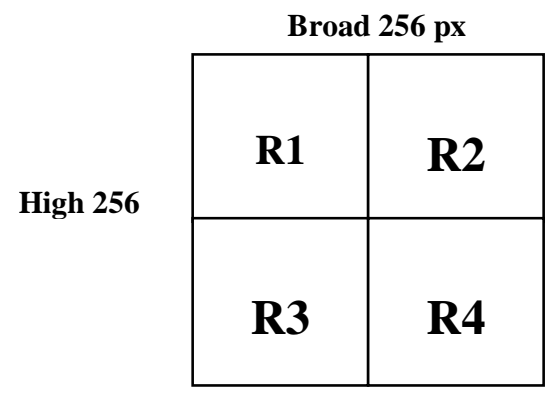

Figure 2. The division of regions in the input image after normalized to $256 \mathrm{x}$ 256 pixels.

\section{Fuzzy Inference System Module}

The system is twofold: itten fuzzy inference systems that are used to determine the type of colors based on itten-Runge sphere and 
sensation fuzzy inference system that is used to determine the sensation of an image. Both use a method of Mamdani. The use of both fuzzy systems have been tested with accuracy of $73.33 \%$ [9].

\section{Itten Fuzzy Inference System}

Fuzzy inference system in determining the type of color-Runge sphere itten draws on research of Frediansah and Endah [10]. In that study, the input in the form of fuzzy inference system component values of red, green and blue color system RGB (Red Green Blue) of color, where the RGB value of color is 0 to 255. Input variables of the fuzzy inference system there are 3, namely the Red variable, Green variable and Blue variable correspond to the RGB color model. In this system, the value Red in a region obtained from the average value of the Red component in each pixel in the region concerned. Likewise with Blue and Green values obtained from the average value of the components of Blue and Green in each of the pixels within each region. Each variable has 5 triangular membership functions, namely low, lowmedium, medium, medium-high and high. Figure 3 berikut ini adalah membership function untuk variabel inputnya.

Output variable membership functions which amounts to 13 be also organized as triangle consists of 12 colors on itten-Runge sphere plus one neutral color, that is for colors that do not exist in itten-Runge sphere, including black, white and color between black and white (gray). Figure 4 menunjukkan membership function untuk variabel outputnya.

Rules (rules) used amounted to 29 rules, including:

1. If (Red is high) and (Green is low) and (Blue is low) then (Itten is red)

2. If (Red is high) and (Green is high) and (Blue is low) then (Itten is yellow)

3. If (Red is low) and (Green is high) and (Blue is low) then (Itten is green)

4. If (Red is low) and (Green is low) and (Blue is low) then (Itten is blue)

5. If (Red is low) and (Green is high) and (Blue is high) then (Itten is green-blue)

6. If (Red is high) and (Green is high) and (Blue is high) then (Itten is neutral)
Defuzzifikasi method used was centroid method. Figure 5 describes the process in this itten fuzzy inference system.

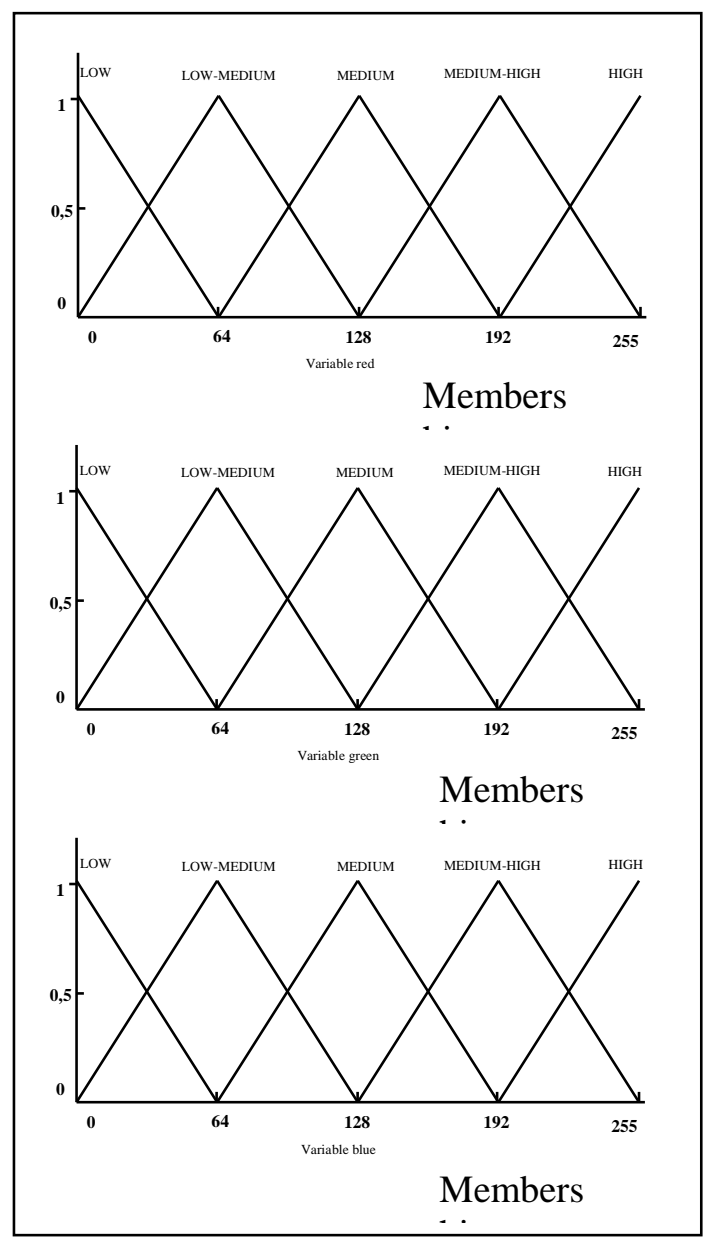

Figure 3. Membership function of input variabel

\section{Sensation Fuzzy Inference System}

This sensation fuzzy inference system is the main module to detect the sensation of an image. Itten value their input in the form of four regions in the image of a fuzzy inference system itten. The combination of itten color values of each of the region which determines the sensation of an image, consists of 4 input variables namely $\mathrm{R} 1, \mathrm{R} 2, \mathrm{R} 3$ and $\mathrm{R} 4$ which shows the image region.

Each variable has 13 triangular-shaped membership function that covers 12 itten color and a neutral color. While the output variable from the sensation which consists of five membership functions are triangular, which is warm, relaxed, live, upset and cold. Range of values used in the variable output is $0-1$. the membership functions used in this system is shown in Figure 6 and Figure 7. 
26 Jurnal Ilmiah KURSOR Vol. 8, No. 1, July 2015, hlm. 21-32

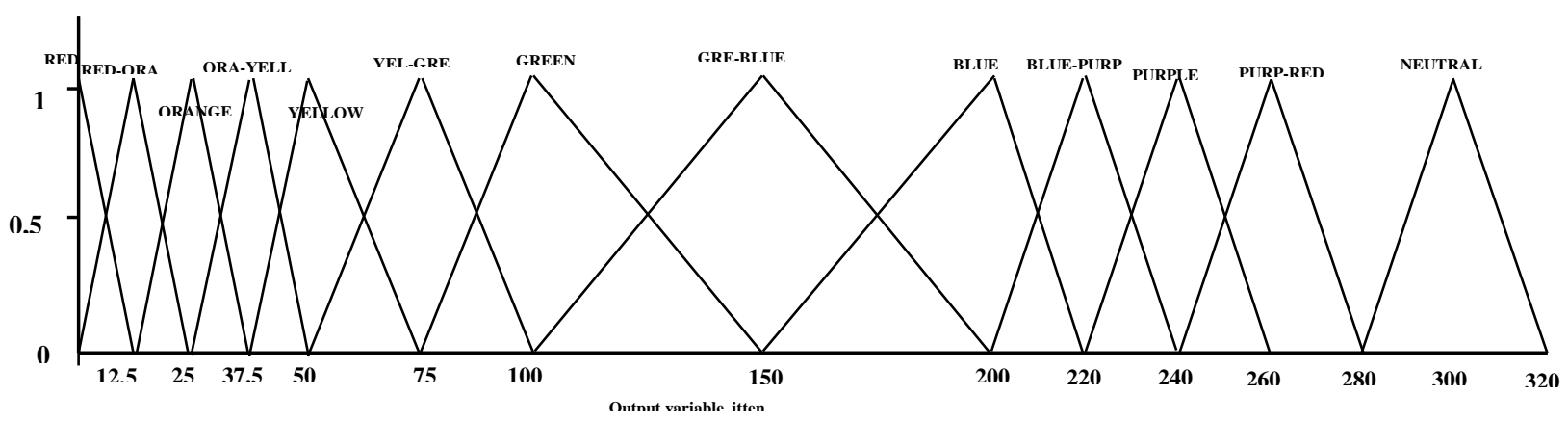

Figure 4. Membership function of output variabel

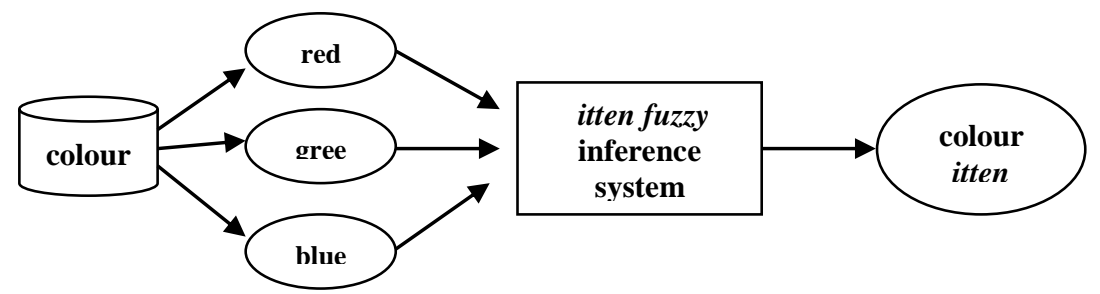

Figure 5. The process of itten fuzzy inference
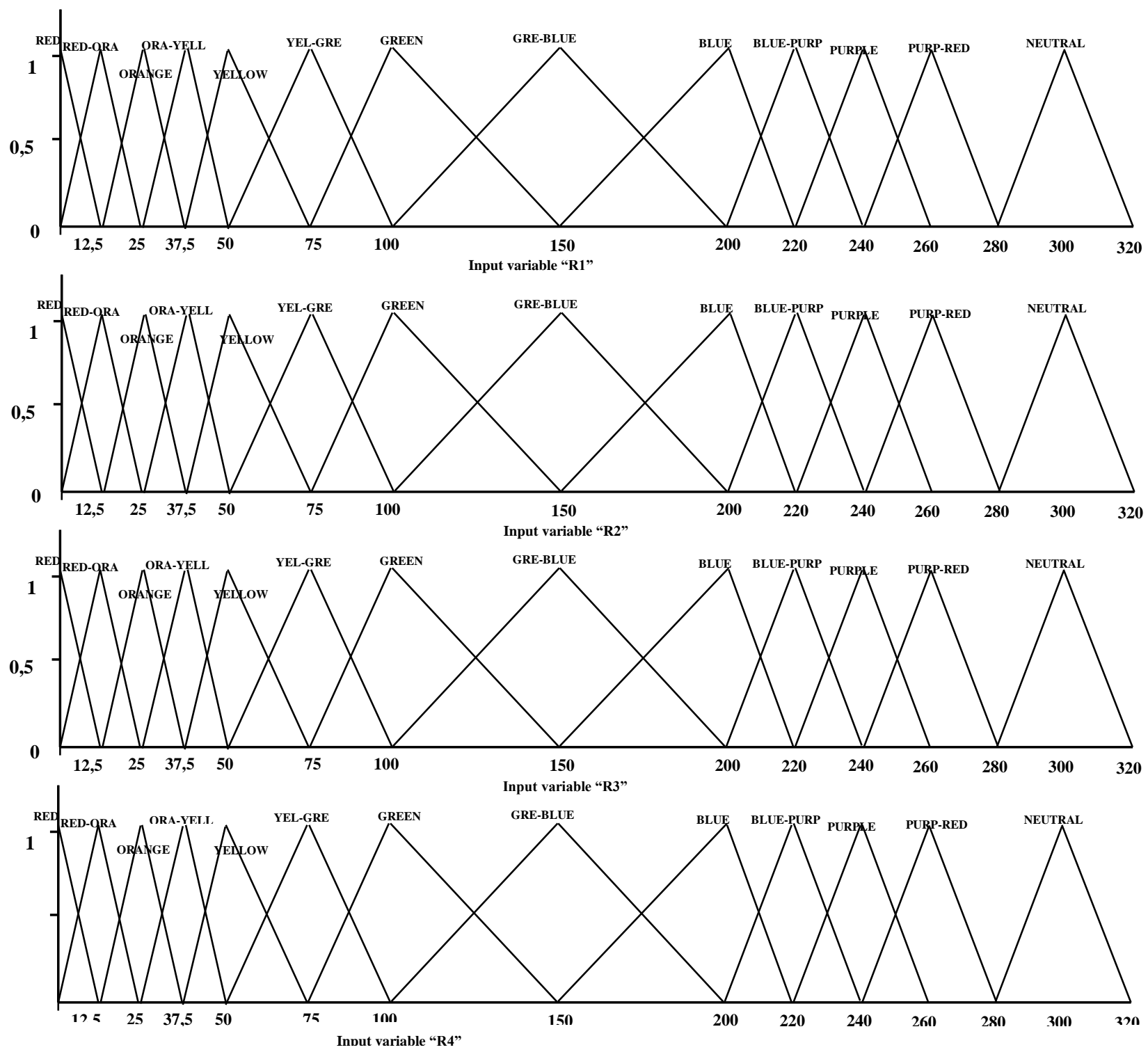

Figure 6. Membership function for the input of Sensation Fuzzy Inference System 
Rules in Sensation Fuzzy Inference System amounted to 341 pieces. This rule refer to on Itten's theory, including:

1. If (R1 is orange) and (R2 is orange) and (R3 is orange) and (R4 is orange) then (Sensation is Warm)

2. If ( $\mathrm{R} 1$ is green) and (R2 is green) and (R3 is green) and (R4 is green) then (Sensation is Cold)

3. If (R1 is purple) and (R2 is orange-red) and (R3 is blue-green) and (R4 is yellow) then (Sensation is Life)

4. If (R 1 is red) and (R2 is orange-yellow) and ( $\mathrm{R} 3$ is green) and ( $\mathrm{R} 4$ is blue-purple) then (Sensation is Life)

5. If ( $\mathrm{R} 2$ is orange-yellow) and ( $\mathrm{R} 3$ is bluegreen) and (R4 is purple red) then (Sensation is Life)

6. If (R1 is orange) and (R2 is orange-yellow) and (R3 is orange-yellow) and (R4 is orange) then (The sensation is depressed)

7. If ( $\mathrm{R} 1$ is green) and ( $\mathrm{R} 2$ is yellow green) and ( $\mathrm{R} 3$ is green) and (R4 is yellow-green) then (The sensation is depressed)

8. If ( $\mathrm{R} 1$ is yellow) and ( $\mathrm{R} 2$ is purple) and ( $\mathrm{R} 3$ is purple) and (R4 is yellow) then (Sensation is Relaxed)

9. If ( $\mathrm{R} 1$ is red) and ( $\mathrm{R} 2$ is green) and ( $\mathrm{R} 3$ is red) and (R4 is green) then (Sensation is Relaxed)
10. If ( $\mathrm{R} 2$ is orange-yellow) and (R3 is orangeyellow) and ( $\mathrm{R} 4$ is orange-yellow) then (Sensation is Warm)

Figure 8 shows the process of sensation fuzzy inference systems. While the description of the process of itten fuzzy inference systems combined with the sensation of a fuzzy inference system:

1. Search By Query Module

Search module based on this query has a function to iterate and calculate the value of the sensation of each image data in the database. One by one, image data that is in the database image is taken, then using a fuzzy inference system module sensation value calculated from the image data, if the results are in accordance with the input query, the data is stored for later display the results. From the image data in a database obtained from the region itten color values for each image, itten value of each region is used for calculating the sensation of using fuzzy inference system module sensation. Figure 10 describes the process of search by query module.

It has been described for the image query, not only the known types of sensation, but also the sensation, therefore, if the insert using a image query, then the result data obtained from searches on this data base, will be sorted from the most similar to the sensation before displayed.

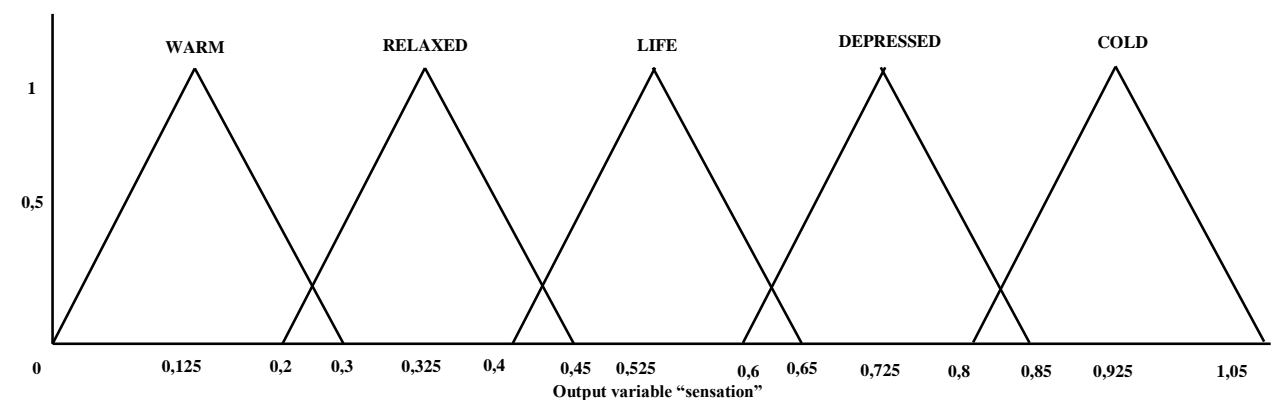

Figure 7. Membership function for the output of Sensation Fuzzy Inference System

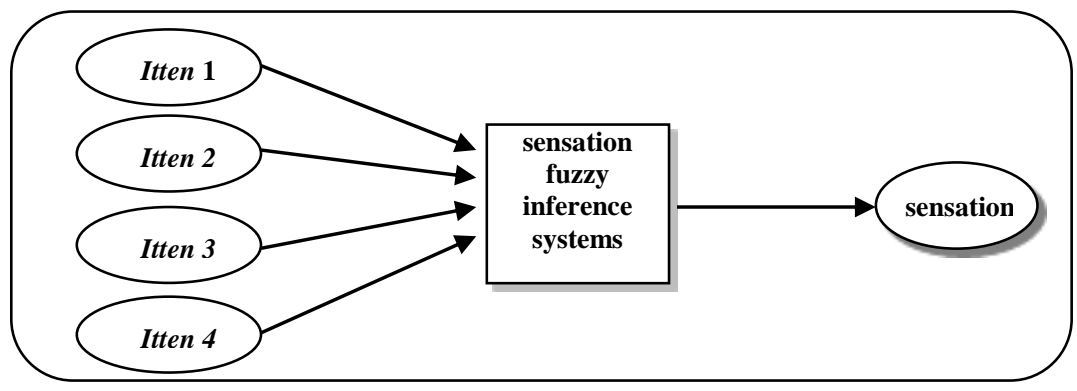

Figure 8 . The process of sensation fuzzy inference systems 
28 Jurnal Ilmiah KURSOR Vol. 8, No. 1, July 2015, hlm. 21-32

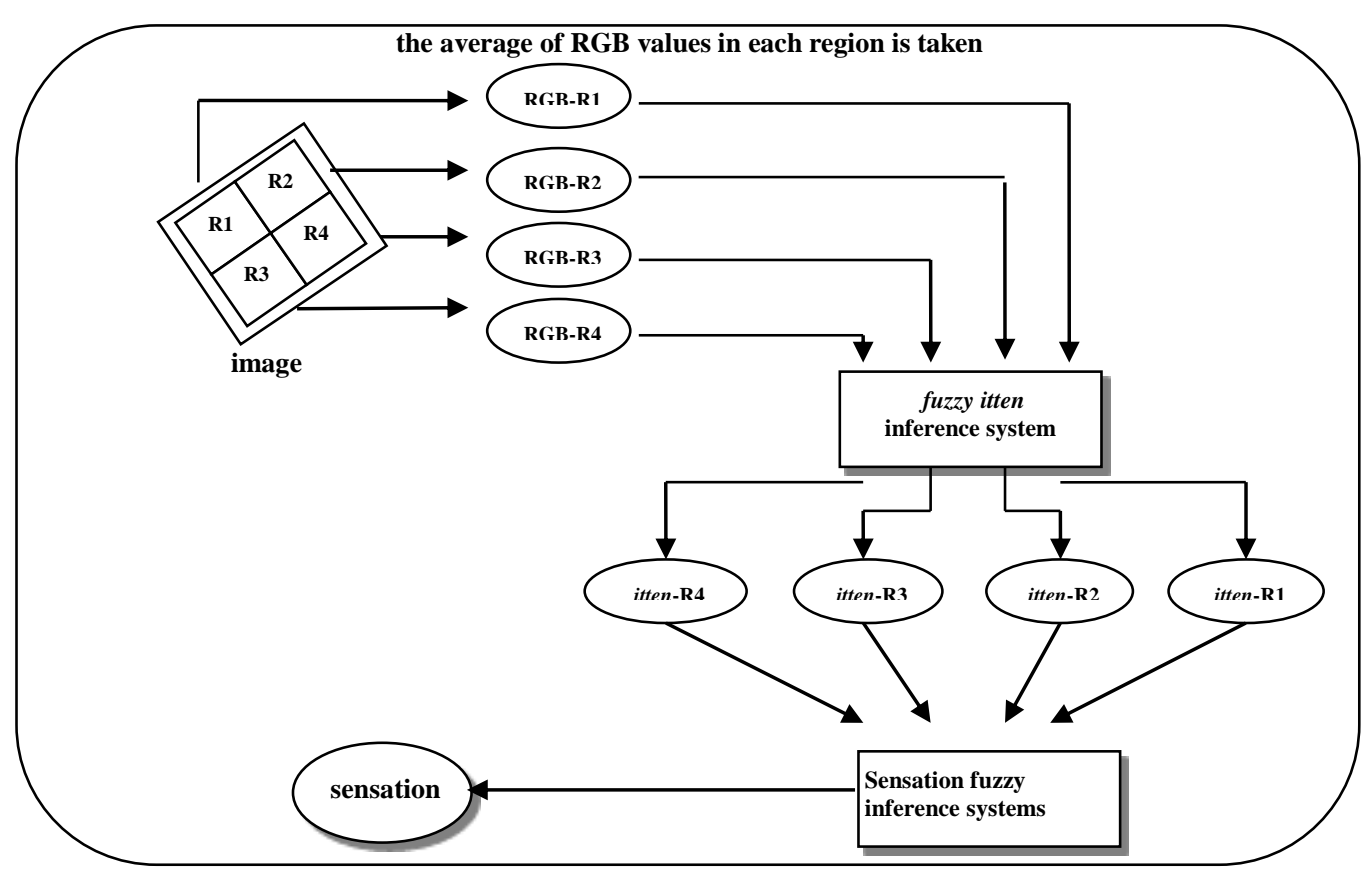

Figure 9. The process of fuzzy inference system combined itten and sensation

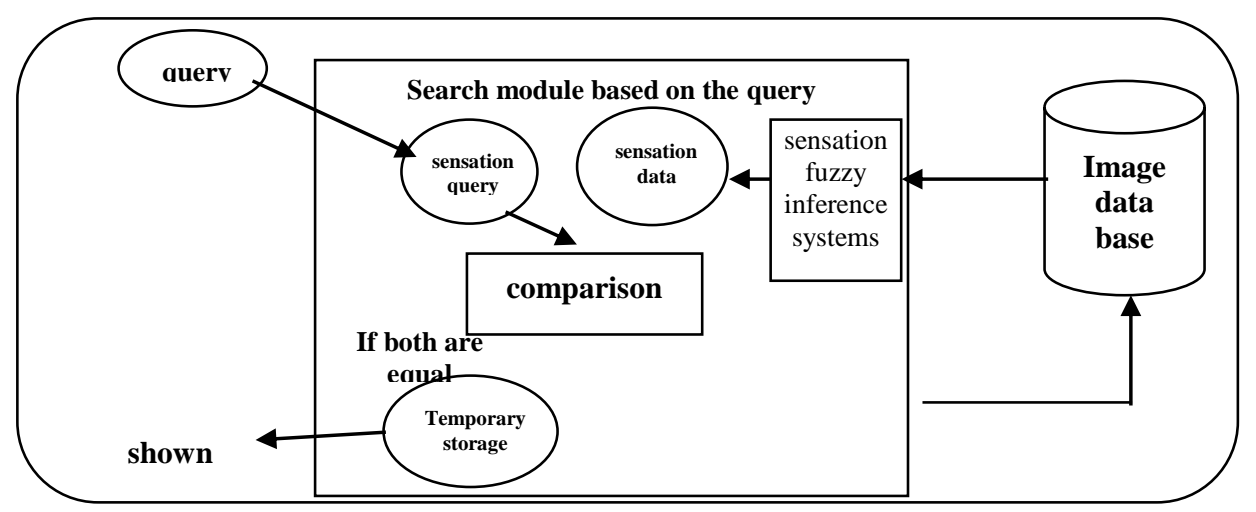

Figure 10. The process of the search module query

2. Image Data Manager Module

This module serves for the management of image data base, which includes displaying the image data, input new image and erase the existing image. This module has a separate interface with the main interface window. To display the image data is used like a table, and to insert a new image from outside the given input file can take from the outside.

\section{RESULT AND DISCUSSION}

\section{Mechanical Testing}

The data used in testing the number of fifty images, and images are included in the data base retrieval applications of multi-image query. The 50 (fifty-image) is tested by using a query in the form of text and image queries.
The results of the system output compared with results observed using the human eye, i.e. by the respondent. In this test involves a 20 (twenty) of the respondents.

\section{Testing Text Query}

Testing a text query is done by trying one by one type of queries that can be inserted according to the sensation that there is, namely a warm, relaxed, depressed, cold and living. Each type of sensation recorded images into the category of sensation. Then the results are compared with results from observations of respondents who see with the naked eye. Comparing the results of the largest percentage of respondents would use the sensation of each option on each image. Because of the diversity of respondents in the observed color capability and capacity factors of respondents in understanding the sensation of the image is 
still lacking, this study drew the conclusion of the test using the following rules. 20\%). An image of the test results will be accepted if the sensation generated by the system chosen by 4 respondents or more $(\geq 20 \%)$. This number is taken with the consideration that every sensation has the same opportunities. So that the number of respondents (20): the number of sensations $(5)=4$ or $100 \%: 5=20 \%$.

\section{Testing Image Query}

Testing the Image query is also done with the help of the same respondents as many as twenty people. Testing is done by asking common sense image of the output of the system, the image query as much as twenty test images. Originally performed by image query processing system then selected 3 (three) image of outcomes that are considered to be the image have systems sensation similar to the input image query, with a selection of 3 (three) carried out semi-random images. Then from the image query and the image of the results is shown to the respondents and asked whether the sensation of the image that was put together with the sensations in the output image. Previous respondents were not informed that the image was already a sensation similar result in a multi-image retrieval system of this query. Assuming that respondents are less experienced in assessing the sensation of an image, then the conclusions will be accepted if the respondent's answer is correct $50 \%$ or more.

\section{Testing Results}

The results of the testing system is based on the comparison of observations of the respondents with the results of the system. Figure 11 shows samples of image for each sensation.

Comparison chart sensation image processed by the system and by observation of the respondents as many as 20 (twenty) people is seen in Table 2. Table 3 shows The data results from the opinion of respondents to the output by using a image query.

\section{Analysis Of Test Results}

From the comparison test for text queries are 21 (twenty one) or $42 \%$ (forty-two percent) of the received output system. As for the image query data received is 11 (thirteen) of 20 (twenty) samples, or the percentage of $55 \%$ (fifty-five percent) of the received output system.

The table 4 shows the level of testing accuracy for text queries. Many images were rejected or not in accordance with the observations of respondents indicated that the fuzzy inference system that is built is still less than perfect applications for this image retrieval system. This can happen on the rules and membership functions in the range of each input and output variables. As for living and relaxing sensation that almost its entire image is rejected, due to the possibility because of the color composition is almost similar to the sensation of another, so that respondents difficult to distinguish.

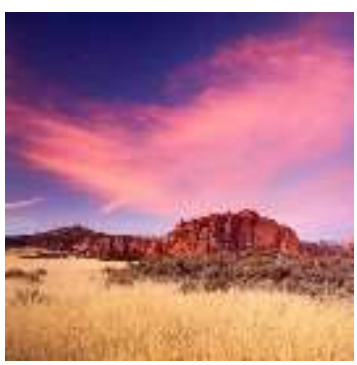

(a)

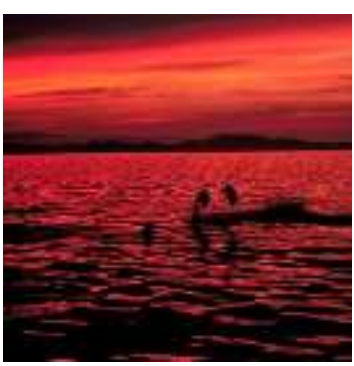

(c)

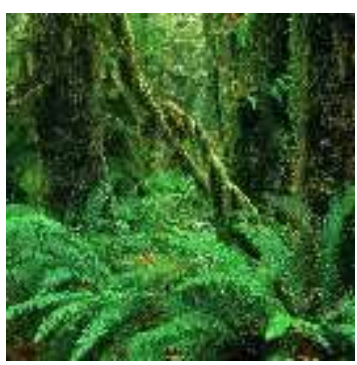

(b)

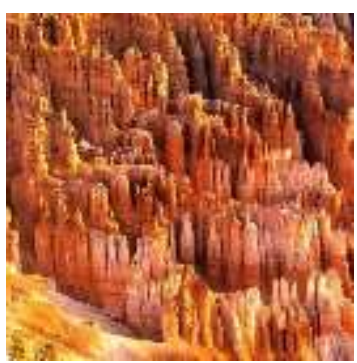

(d)

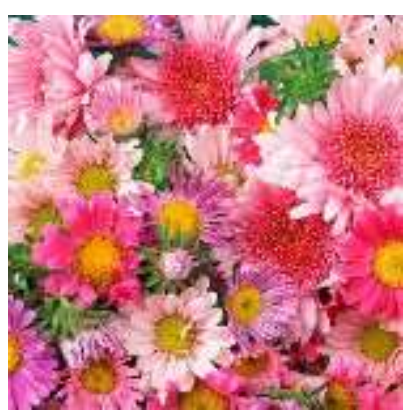

(e)

Figure 11. Sample image with (a) warm; (b) cold; (c) relaxed; (d) depressed; (e) life sensation

In testing the image query, the low likelihood of respondents who correctly 
answered the Image query and the image of the results have a much different color composition, so that respondents would conclude that the image is a different sensation. Moreover, respondents to this study are really about the sensation of a cloud image.

\section{CONCLUSIONS}

Based on the previous explanation it can be concluded that the need for accuracy in determining the parameters for each membership function in a fuzzy system and its rules so as to produce an application that actually has a high degree of accuracy. In addition to the color composition of each sensation differ very thin so it takes a lot of rules in order to cover everything. This research can be developed further by improving the range, the parameters and rules in the fuzzy inference system that produces a rich level of accuracy.

Table 2. The Comparison of Observations of the Respondents with the Results of the System

\begin{tabular}{|c|c|c|c|c|c|c|c|c|}
\hline \multirow{2}{*}{ No } & \multirow{2}{*}{ Image } & \multirow{2}{*}{$\begin{array}{l}\text { Application's } \\
\text { answer }\end{array}$} & \multicolumn{5}{|c|}{ Respondent's answer } & \multirow{2}{*}{ conclusions } \\
\hline & & & Warm & Cold & Relaxed & Depressed & Life & \\
\hline 1 & Image01.jpg & Life & $40 \%$ & $20 \%$ & $20 \%$ & $10 \%$ & $10 \%$ & Rejected \\
\hline 2 & Image02.jpg & Warm & $35 \%$ & $5 \%$ & $35 \%$ & $25 \%$ & $0 \%$ & Received \\
\hline 3 & Image03.jpg & Warm & $55 \%$ & $5 \%$ & $15 \%$ & $15 \%$ & $10 \%$ & Received \\
\hline 4 & Image04.jpg & Cold & $0 \%$ & $80 \%$ & $0 \%$ & $10 \%$ & $10 \%$ & Received \\
\hline 5 & Image05.jpg & Warm & $25 \%$ & $5 \%$ & $15 \%$ & $40 \%$ & $15 \%$ & Received \\
\hline 6 & Image06.jpg & Relax & $75 \%$ & $0 \%$ & $\underline{10 \%}$ & $0 \%$ & $15 \%$ & Rejected \\
\hline 7 & Image07.jpg & Relax & $30 \%$ & $0 \%$ & $\overline{10 \%}$ & $45 \%$ & $15 \%$ & Rejected \\
\hline 8 & Image08.jpg & Warm & $35 \%$ & $0 \%$ & $25 \%$ & $35 \%$ & $5 \%$ & Received \\
\hline 9 & Image09.jpg & Warm & $40 \%$ & $5 \%$ & $15 \%$ & $25 \%$ & $15 \%$ & Received \\
\hline 10 & Image10.jpg & Cold & $0 \%$ & $50 \%$ & $5 \%$ & $10 \%$ & $35 \%$ & Received \\
\hline 11 & Image11.jpg & Cold & $0 \%$ & $70 \%$ & $15 \%$ & $15 \%$ & $0 \%$ & Received \\
\hline 12 & Image 12.jpg & Warm & $45 \%$ & $0 \%$ & $10 \%$ & $30 \%$ & $15 \%$ & Received \\
\hline 13 & Image13.jpg & Cold & $5 \%$ & $5 \%$ & $30 \%$ & $0 \%$ & $60 \%$ & Rejected \\
\hline 14 & Image 14.jpg & Cold & $0 \%$ & $5 \%$ & $20 \%$ & $0 \%$ & $75 \%$ & Rejected \\
\hline 15 & Image 15.jpg & Cold & $0 \%$ & $20 \%$ & $25 \%$ & $20 \%$ & $35 \%$ & Received \\
\hline 16 & Image16.jpg & Cold & $0 \%$ & $15 \%$ & $35 \%$ & $15 \%$ & $35 \%$ & Rejected \\
\hline 17 & Image 17.jpg & Warm & $25 \%$ & $0 \%$ & $5 \%$ & $70 \%$ & $0 \%$ & Received \\
\hline 18 & Image18.jpg & Cold & $0 \%$ & $0 \%$ & $45 \%$ & $10 \%$ & $45 \%$ & Rejected \\
\hline 19 & Image19.jpg & Cold & $85 \%$ & $0 \%$ & $0 \%$ & $10 \%$ & $5 \%$ & Rejected \\
\hline 20 & Image20.jpg & Cold & $5 \%$ & $10 \%$ & $20 \%$ & $0 \%$ & $65 \%$ & Rejected \\
\hline 21 & Image 21.jpg & Cold & $5 \%$ & $15 \%$ & $35 \%$ & $0 \%$ & $45 \%$ & Rejected \\
\hline 22 & Image22.jpg & Cold & $5 \%$ & $0 \%$ & $10 \%$ & $45 \%$ & $40 \%$ & Rejected \\
\hline 23 & Image23.jpg & Cold & $25 \%$ & $5 \%$ & $25 \%$ & $25 \%$ & $20 \%$ & Rejected \\
\hline 24 & Image24.jpg & Cold & $5 \%$ & $10 \%$ & $20 \%$ & $0 \%$ & $65 \%$ & Rejected \\
\hline 25 & Image25.jpg & Cold & $15 \%$ & $10 \%$ & $25 \%$ & $20 \%$ & $30 \%$ & Rejected \\
\hline 26 & Image26.jpg & Warm & $40 \%$ & $5 \%$ & $10 \%$ & $30 \%$ & $15 \%$ & Received \\
\hline 27 & Image27.jpg & Warm & $40 \%$ & $10 \%$ & $10 \%$ & $30 \%$ & $10 \%$ & Received \\
\hline 28 & Image28.jpg & Warm & $65 \%$ & $5 \%$ & $10 \%$ & $10 \%$ & $10 \%$ & Received \\
\hline 29 & Image29.jpg & Cold & $5 \%$ & $15 \%$ & $25 \%$ & $0 \%$ & $55 \%$ & Rejected \\
\hline
\end{tabular}


Table 2. The Comparison of Observations of the Respondents with the Results of the System (contd.)

\begin{tabular}{|c|c|c|c|c|c|c|c|c|}
\hline \multirow{2}{*}{ No } & \multirow{2}{*}{ Image } & \multirow{2}{*}{$\begin{array}{l}\text { Application's } \\
\text { answer }\end{array}$} & \multicolumn{5}{|c|}{ Respondent's answer } & \multirow{2}{*}{ conclusions } \\
\hline & & & Warm & Cold & Relaxed & Depressed & Life & \\
\hline 30 & Image30.jpg & Cold & $10 \%$ & $5 \%$ & $45 \%$ & $0 \%$ & $40 \%$ & Rejected \\
\hline 31 & Image31.jpg & Cold & $5 \%$ & $35 \%$ & $15 \%$ & $0 \%$ & $45 \%$ & Received \\
\hline 32 & Image32.jpg & Life & $65 \%$ & $5 \%$ & $0 \%$ & $20 \%$ & $10 \%$ & Rejected \\
\hline 33 & Image33.jpg & Cold & $0 \%$ & $45 \%$ & $10 \%$ & $10 \%$ & $35 \%$ & Received \\
\hline 34 & Image34.jpg & Life & $40 \%$ & $0 \%$ & $0 \%$ & $55 \%$ & $\underline{5 \%}$ & Rejected \\
\hline 35 & Image35.jpg & Cold & $90 \%$ & $5 \%$ & $0 \%$ & $5 \%$ & $0 \%$ & Rejected \\
\hline 36 & Image36.jpg & Cold & $0 \%$ & $10 \%$ & $30 \%$ & $30 \%$ & $30 \%$ & Rejected \\
\hline 37 & Image37.jpg & Cold & $20 \%$ & $30 \%$ & $5 \%$ & $35 \%$ & $10 \%$ & Received \\
\hline 38 & Image38.jpg & Cold & $80 \%$ & $0 \%$ & $5 \%$ & $10 \%$ & $5 \%$ & Rejected \\
\hline 39 & Image39.jpg & Cold & $0 \%$ & $45 \%$ & $5 \%$ & $10 \%$ & $40 \%$ & Received \\
\hline 40 & Image40.jpg & Cold & $25 \%$ & $5 \%$ & $15 \%$ & $55 \%$ & $0 \%$ & Rejected \\
\hline 41 & Image41.jpg & Cold & $5 \%$ & $5 \%$ & $30 \%$ & $0 \%$ & $60 \%$ & Rejected \\
\hline 42 & Image42.jpg & Cold & $5 \%$ & $15 \%$ & $15 \%$ & $0 \%$ & $65 \%$ & Rejected \\
\hline 43 & Image43.jpg & Warm & $35 \%$ & $0 \%$ & $25 \%$ & $5 \%$ & $35 \%$ & Received \\
\hline 44 & Image44.jpg & Warm & $0 \%$ & $0 \%$ & $45 \%$ & $20 \%$ & $35 \%$ & Rejected \\
\hline 45 & Image45.jpg & Cold & $0 \%$ & $20 \%$ & $25 \%$ & $25 \%$ & $30 \%$ & Received \\
\hline 46 & Image46.jpg & Warm & $0 \%$ & $0 \%$ & $20 \%$ & $25 \%$ & $55 \%$ & Rejected \\
\hline 47 & Image47.jpg & Relax & $10 \%$ & $0 \%$ & $35 \%$ & $5 \%$ & $50 \%$ & Received \\
\hline 48 & Image48.jpg & Cold & $25 \%$ & $0 \%$ & $25 \%$ & $30 \%$ & $20 \%$ & Rejected \\
\hline 49 & Image49.jpg & Relax & $30 \%$ & $10 \%$ & $10 \%$ & $25 \%$ & $25 \%$ & Rejected \\
\hline 50 & Image50.jpg & Cold & $35 \%$ & $0 \%$ & $25 \%$ & $30 \%$ & $10 \%$ & Rejected \\
\hline
\end{tabular}

Table 3. Data From Respondents' Opinions of the Input Image Query

\begin{tabular}{ccccc}
\hline \multirow{2}{*}{ No } & Respondent & \multicolumn{2}{c}{$\begin{array}{c}\text { Quizioner's } \\
\text { answer }\end{array}$} & Conclusion \\
\cline { 3 - 4 } & & True & Wrong & \\
\hline 1 & responsi(1).jpg & $15 \%$ & $85 \%$ & Rejected \\
2 & responsi(2).jpg & $45 \%$ & $55 \%$ & Rejected \\
3 & responsi(3).jpg & $65 \%$ & $35 \%$ & Received \\
4 & responsi(4).jpg & $75 \%$ & $25 \%$ & Received \\
5 & responsi(5).jpg & $50 \%$ & $50 \%$ & Received \\
6 & responsi(6).jpg & $85 \%$ & $15 \%$ & Received \\
7 & responsi(7).jpg & $60 \%$ & $40 \%$ & Received \\
8 & responsi(8).jpg & $85 \%$ & $15 \%$ & Received \\
9 & responsi(9).jpg & $40 \%$ & $60 \%$ & Rejected \\
10 & responsi(10).jpg & $40 \%$ & $60 \%$ & Rejected \\
11 & responsi(11).jpg & $45 \%$ & $55 \%$ & Rejected \\
12 & responsi(12).jpg & $5 \%$ & $95 \%$ & Rejected \\
13 & responsi(13).jpg & $55 \%$ & $45 \%$ & Received \\
14 & responsi(14).jpg & $60 \%$ & $40 \%$ & Received \\
15 & responsi(15).jpg & $50 \%$ & $50 \%$ & Received \\
16 & responsi(16).jpg & $70 \%$ & $30 \%$ & Received \\
17 & responsi(17).jpg & $10 \%$ & $90 \%$ & Rejected \\
18 & responsi(18).jpg & $80 \%$ & $20 \%$ & Received \\
19 & responsi(19).jpg & $35 \%$ & $65 \%$ & Rejected \\
20 & responsi(20).jpg & $10 \%$ & $90 \%$ & Rejected \\
\hline
\end{tabular}


Table 4. Degree of Accuracy in Testing the Text Query

\begin{tabular}{|c|c|c|c|c|c|}
\hline \multirow[t]{2}{*}{ No } & \multirow[t]{2}{*}{ Sensation } & \multirow{2}{*}{$\begin{array}{l}\text { Total of system } \\
\text { Image result }\end{array}$} & \multicolumn{2}{|c|}{ Respondent's monitoring } & \multirow{2}{*}{$\begin{array}{l}\text { Degree of } \\
\text { Accuracy }\end{array}$} \\
\hline & & & Received & Rejected & \\
\hline 1 & Warm & 13 & 11 & 2 & $85 \%$ \\
\hline 2 & Relax & 4 & 1 & 3 & $25 \%$ \\
\hline 3 & Life & 3 & 0 & 3 & $0 \%$ \\
\hline 4 & Depressed & 0 & 0 & 0 & - \\
\hline 5 & Cold & 30 & 9 & 21 & $30 \%$ \\
\hline & Total & 50 & 21 & 29 & \\
\hline
\end{tabular}

\section{REFERENCES}

[1] Veltcamp C Remco and Mirela Tanase, "Content-Based Image Retrieval Systems : A Survey," Technical Report UU-CS2000-34, 2000.

[2] Ika Alfina and M. Rahmat Widyanto, "Sistem Temu kembali Image untuk Sensasi Berbasis Teori Fuzzy," in Proceedings of national Conference on Computer Science \& Information Technology, 2007.

[3] Zoran Steji'C, Y. Takama, and K Hirota, "Integrated Retrieval of Images and Text :Image Indexing Using Sensitivity Expressions," in The 37 th Seminar on Intelligent Control (SIC2000-1), 2000, pp. 15-18.

[4] S Antani, LR Long, and GR Thoma, "A biomedical information system for combined content-based retrieval of spine $\mathrm{x}$-ray images and associated text information," in 3rd Indian Conference on Computer Vision, Graphics, and Image Processing (ICVGIP '02), Ahemdabad, India, 2002, pp. 242-247.

[5] M. Flickner, "Query by Image and Video Content : The QBIC System," IEEE Computer, vol. 28, no. 9, pp. 23-32, September 1995.

[6] George Paschos, "Perceptually Uniform Color Spaces for Color Texture Analysis :
An Empirical Evaluation," IEEE Transactions on Image Processing, vol. 10, no. 6, June 2001.

[7] Traina, A.J.M Balan, A.G.R. Bortolotti, and L.M C.,Jr Traina, "Content-Based Image Retrieval using approximaate shape of objects," in 17th IEEE Symposium on Computer-Based Medical Systems, 2004.

[8] Johannes Itten,. Ravenburg, Germany: Otto Maier Verlag, 1961.

[9] Sukmawati Nur Endah, Priyo Sidik, Helmie Arif, and Frediansah, "Sistem Inferensi Fuzzy untuk Menentukan Sensasi Warna," Jurnal Masyarakat Informatika, vol. 1, no. 2, october 2010.

[10] Frediansah and Sukmawati Nur Endah, "Penggolongan Warna dalam Itten-Runge Sphere dengan Sistem Inferensi Fuzzy," in Prosiding Seminar Nasional Ilmu Komputer Universitas Diponegoro 2010, Semarang, 2010. 